\title{
CORRIGENDUM
}

\section{Nuclear actin and myosins: Life without filaments}

\section{Primal de Lanerolle and Leonid Serebryannyy}

Nat. Cell Biol. 13, 1282-1288 (2011); published online 2 November 2011; corrected after print 29 April 2015

In the version of this Review originally published the authors inadvertently omitted a key reference. This has now been added to the caption of Fig. 3 in the online version: 'The actin-binding protein WASP has been discovered in the nucleus and modulates transcription independently or with the ARP2/3 complex ${ }^{97}$.

97. Taylor, M. D. et al. Nuclear role of WASp in the pathogenesis of dysregulated $\mathrm{T}_{\mathrm{H}} 1$ immunity in human Wiskott-Aldrich syndrome. Sci. Transl. Med. 2, 37ra44 (2010).

Corrected after print 14 May 2015

In the version of this Review originally published reference 34 should have appeared in the caption of Fig. 3: 'The actin-binding protein WASP has been discovered in the nucleus and modulates transcription independently or with the ARP2/3 complex ${ }^{34,97}$. This has been corrected in the online versions of the Review. 